\title{
SOCIO-CULTURAL VALUES AND CHILDREN'S RIGHTS IN CALABAR
}

\author{
EKWUTOSI E. OFFIONG ${ }^{1} \&$ GODSPOWER ANDREW UDUIGWOMEN ${ }^{2}$ \\ 1 University of Calabar, Department of History and International Studies, Calabar. ORCID: \\ 0000-0002-9913-7300, Email: ekwutosioffiong@gmail.com \\ 2 University of Calabar, Department of History and International Studies, Calabar. ORCID: \\ 0000-0003-3515-0212, Email: godspoweruduigwomen@gmail.com
}

\begin{abstract}
This paper on Socio-Cultural Values and Children's Rights in Calabar analyses the history and value system associated with child upbringing in the city of Calabar. Communalism, which ensured child socialisation from birth, was a common practice in Calabar like in other areas of Africa and Nigeria until European incursion and eventual introduction of capitalism during colonial times. This change resulted in the diminishing of communal lifestyle and reduction of family sizes to nuclear forms. It also necessitated the population increase and related social problems. Although historical in content and analysis, the paper adopted the multidisciplinary approach of reconstruction with data gleaned from primary and secondary sources. Findings showed that right from pre-colonial times, inhuman practices that abused children's rights like child pawning and killing of twins characterised this study area. Population increase and the rise of urban poor and slums resulted in the breeding of abused children, with most homeless on the streets of Calabar. Witchcraft labelling and child trafficking were also highlighted as other significant and recurring causes of child abuse in Calabar. This paper concluded by reiterating that as Calabar flouts its status as a 'restful city', children must not be denied of this 'restful' lifestyle. Child rights must be implementable and child right violators prosecuted.

KEYWORDS: culture, Children's Rights, common practices, social problems, inhuman practices, child abuse
\end{abstract}




\section{INTRODUCTION}

$\mathrm{H}$ istory, as a discipline, and knowing about the human past, is unique. Without history, the understanding of contemporary issues or realities will certainly be hazy and unenriching. The knowledge of history has undoubtedly gained as a society and also as an individual scholar. At contemporary times, countries or continents of the world are now profiled or stratified, and this is due to actions and inactions of man in such areas in the past. It is now a norm that nations are regarded as developed and underdeveloped (developing), First World and Third World, Global North and South, etc. The knowledge of the world's history can best understand this.

It can no longer be debated that specific studies on children or childhood history began globally in the twentieth century due to events that necessitated this (Western Civilisation, World Wars, European Imperialism etc.). However, this does not insinuate that there were no studies on children before this era. It is important to stress that most developed or First World countries of today had their civilisation early, which in turn enabled early documentation of literature. This also enabled the rise of Eurocentric or Western methodologies and views of the human past before the nineteenth century. Although it had documented analysis majorly from the nineteenth and twentieth centuries, Africa or Africans had their own unique form of documentation or accounts of events that most African historians termed as the unwritten source or primary sources. From the early twentieth century, historians and scholars writing about Africa had cited or based their analyses on this source/methodology over time. Therefore, it will be wrong to assume that issues relating to children in African societies were unknowledgeable or were unavailable before European interference. This explains the methodology used in the documentation of this paper. Primary sources, therefore, are simply unpublished sources. They are diaries, minutes of meetings, letters, newspapers, oral evidence etc. (Majuk 2001: 59). In comparison, secondary sources are usually interpretations and judgements based on primary sources and are in the form of journals and books resulting from original research (Majuk 2001: 59). It is imperative to note that there must be coherence or compatibility among all disciplines in the documentation of African history. African historians found themselves logically concatenated in a system so tight that subtracting one item from the whole was to destroy the whole structure (Uya 2009: 12). Hence, "the result of this was the insistence that African history has to be approached from the interdisciplinary angle" (Uya 2009: 12).

Aderinto (2015) is of the view that although "historians generally agree that the publication of Centuries of Childhood, by Philippe Aries in 1962, originally in French titled L'Enfant et la vie familiale sous l'Ancien Régime (1960); ... no one before him placed childhood as a significant component of Western civilisation and history" (Aderinto 2015: 4). This made his publication novel and pivotal in subsequent studies and decisions on children's welfare in most nations and organisations. It is, however, important to stress at this point that African historians will also agree with Aderinto (2015) that due to the nature of African history, as compared to European history, any serious historical work on Africa (especially Nigeria) would not subscribe to Aries' idea of the 
absence of childhood or the notion of its "invention" at any period in African history. Neither would it accept the notion that the persistently high mortality rate prevented parents from emotionally investing in their children (Aderinto 2015: 4). This instigates a foreknowledge that children played a central role in Africa's history and that this view should not be restricted to the West. Furthermore, issues on child upbringing or welfare highlighted subsequently will affirm this place of children in Africa's history and civilisation, although marred by some inhumane behaviours that abused children's rights. This does not underscore the centrality of children in Africa's history, as seen in contemporary literature.

The discourse on Child's Right is not relatively new and is not geographically restricted. It is a global discourse because of the sensitivity of the individuals involved (children). More so, issues relating to children are not so contemporary as subsequent records prove that even before international laws were enacted, children's welfare and development were topmost priorities for families, clans, villages, empires, states, etc., in Africa. However, this paper's main thrust is to historically appraise the implementation of universal law (Child Rights) in Nigeria and Calabar, Cross River State (specifically). This cannot be done without adequate knowledge of the history of Calabar, with a clear emphasis on her socio-cultural history in tandem with the values and practices that accompanied child upbringing and welfare.

According to Child Right Act, 2003, a child, as cited in Azi and Saluhu (2016: 23) is a boy or girl between infancy and adolescence and is anyone who has not attained the age of 18 years. A child can also be classified as an infant, toddler, pre-adolescent or adolescent. However, the central literature which serves as a guide to this Paper $-A$ Child's Right to Respect by Korczak (2017), has this to say that: "there are no children - there are people" (Korczak 2017: 6). This insinuates that in an ideal society, dichotomy or class division should be non-existent because it may result in discrimination and unwarranted abuses. Everyone in society should be seen and treated as equals. The above literature targeted the audience of professionals working with children like teachers or educators and social workers. Although the text seemed empathetic and sympathetic to children, it portrays a supposed global standard of child upbringing as ideal, which slightly is different from that of Africa and does not mean that Africans should disregard this literature's content.

\section{A BRIEF HISTORY AND OVERVIEW OF THE SOCIO-CULTURAL SETTING OF CALABAR}

Calabar is the capital city of Cross River State, Nigeria. Calabar is located at latitude $04^{\circ} 57^{\prime}$ North and longitude $08^{\circ} 20^{\prime}$ East and comprises of two Local Government Area Councils - Calabar Municipality and Calabar South. The area now known as Calabar was formerly known as Old-Calabar in pre-colonial times. It is well known to inhabitants and scholars that to the North of Calabar is Ogoja and the Cross River's Oban regions; to the immediate and distant West are Ibibio and Ibo countries respectively; to the near East stretch the regions of West Cameroon (Aye 2000: 1). The city of Calabar is a tripartite capital for the Efik, Qua and the Efut (three ethnic groups). The Efik on 
one side "applies to all descendants of Eburutu tribe, who have retained the originality of their tribal identity" (Aye 2000: 21) and are commonly known as 'EfikEburutu'. On the other side, the Qua are also part of the more prominent Ejagham people's group of the Bantu race and the Ekoi origin and speaks a practically identical dialect with that of the Ejagham (CADIST 3/3/372 1983: 1). While the Efut in the middle, "originally linked ethnically with the Cameroonians" (Aye 2000: 246), had "a long-standing Efik sphere of influence" (Latham 1973: 51) and "can be regarded as Efik in culture and language."

Calabar was stratified into families, houses - group of families, aliens or sojourners and clans of different peoples or ethnic nationalities in pre-colonial and colonial times. Hart (1964), commenting on the Efik, posited that "from the earliest times, therefore, the Efik social structure conformed to the patriarchal system. Society was based on the House or family to use the Efik term Ufok. Each of these houses had an "Akwaetekiet" or common ancestor (...) to whom all the free members of the House here technically related by Blood" (Hart 1964: 46). The Qua, according to Qua Intelligence Report, "consists of 9 towns - Big Qua, Ikpai, Akim, IkotAnsa, IkotOmin, IkotAkasuk, Eta Ekpini, AkimAkim and Odukpani” (CADIST 3/3/372 1983: 2). They live in Clans which are indigenous administrative units with their satellite villages, and the Qua also are grouped into "groups of families or households related by blood who lived in one or more compound formed the ward or house, also known in Qua dialect as Nyo" (Itakpo 1988: 26). The above insinuates that the Qua and Efik practice a similar system (House System). On the Efut, Noah (1980) is of the position that "they were organised on the basis of family and succession passed from father to son" (Noah 1980: 64). As an entity, "the heads of the various families formed the village council which acted as a court whenever the need arose" (Noah 1980: 64). Furthermore, these ethnic groups all had their kings who were later made Paramount Rulers for government control. The Efịk have the Obong, the Efut have the Muri Munene, and the Qua have the Ndidem (Ekpe 2016: 112).

Polygamy was generally practised in Calabar before the British colonisation of the area. Polygamy was generally practised in many areas of present-day Nigeria, and the sole reason was purely economic. In recounting on this study area, Imbua (2012: 30) was of the position that:

Politically, the number of wives and children a man had determined his social standing. Socially, relationships were cemented by marriage alliances, and there was much prestige in begetting many children. A man's wives and children formed his labour force in the economy, and many wives and in-laws made trading transactions easier.

The polygamous nature of Calabar also enhanced intergroup relations and strengthened inter-communal ties. As this study entails, "the Efik, Qua and Efut, despite their varied backgrounds, evolved similar social patterns that acted as an integrative factor for the three groups and facilitated their peaceful stay in Calabar" (Akoda 2002: 62). However, it is essential to establish that aside from this ideal practice associated with this present city in much of the 1900s, it should be noted that traditional practices 
against children were formerly in place. Although Talbot's account during the early years of colonialism suggested that "at the present state of affairs at least no one is left uncared for, and beggars are unknown through the length and breadth of the Ekoi country" (Talbot 1969: 326), the issue of killing of twins or the abandoning of twins or triplets by parents was a common practice in this area during pre-colonial times. This lays a thoughtful foundation that truly, child abuses occurred in the area now known as Calabar. Secondly, from the above, issues relating to child upbringing were relatively effective in Africa. However, traditional practices that abused children's rights were issues that Christian missionaries uncovered and vehemently tackled upon their arrival in Africa. Documentaries were written in this regard, which led to the emergence of existing literature on children in Africa. This then strengthens Aderinto's claim that there is no better place to trace the emergence of modern Nigerian childhood than within the four walls of mission houses that began to spring up along the West African's southern fringes coastline in the first half of the nineteenth century. History books have examined Christianity's introduction to West Africa and the numerous anti-slave trade activities. However, they have refused to acknowledge that mission education laid the foundation of the modern conception of childhood (Aderinto 2015: 5).

Although this precedence as seen above was associated with Calabar's history, the contacts between Calabar and the Europeans, particularly the British and eventual colonisation, made this city to be regarded as a "model of European civilisation for most of South-Eastern Nigeria, gaining its reputation as the granddaughter of the Atlantic" (Aye 2000: 8). The transformation that made Calabar internationally famous was heralded by agents of radically cultural backgrounds whose quest for development did not accord ethnicity and nationality any deterministic role (Imbua \& Offiong 2011: 131). Thereby bringing to bear that Calabar had strong socio-cultural values, which made for the actualisation of its cosmopolitan nature by the middle of the seventeenth century because Calabar was "a crossroad for trade, culture, civilisation and administration” (Imbua \& Offiong 2011: 132). In fact,

Calabar was an excellent corridor for the trans-Atlantic Slave Trade... The first indigenous sovereign to be crowned with regalia sent by Queen Victoria in the whole of colonial Southern Nigeria in 1878 was King Archibong III of Calabar... The first military barracks; first General Hospital (St. Margaret Hospital, presently University of Calabar Teaching Hospital (UCTH) Annex); the first Social Club in Nigeria - The African Club established in 1903; hosted the first-ever competitive football, Cricket, and Field Hockey games in Nigeria; first Roman Catholic Mass celebrated at 19 Boco Street, Calabar in 1903; host the oldest Secondary School in Eastern Nigeria- Hope Waddell Training Institute in 1895. (Odey 2016: 390)

This section has revealed the importance of this study area and the necessity of this study. The history (political) of Nigeria and the Atlantic Slave Trade is incomplete without an extensive mention of this study area. This area, which was known as Old Calabar, was a significant slave depot and also served as the capital of the Oil Rivers Protectorate (1885-1893, the Niger Coast Protectorate (1893-1900) and Southern Ni- 
geria (1900-1906). More so, much has been written about the history of Calabar by scholars from various disciplines. However, an in-depth analysis of childhood history, welfare and children's rights appears scanty; hence, the necessity of this study.

\section{CHILD RIGHT ACTS IN NIGERIA: A HISTORICAL OVERVIEW}

Children make up a large percentage of the human race, population, nation, inhabitants, fellow citizens, and permanent comrades. They have been, will be and are. (Korczak 2017: 27)

Child rights are fundamental freedoms and all children's inherent rights below 18 years irrespective of race or sex. These rights are in two categories: specific child rights and basic child rights (Obiechina 2014: 152). According to UNICEF, the core-specific child rights are birthright, right to a name, family right, and nationality. The following are excerpts of every Nigerian child's fundamental rights documented by Obiechina (2014): developmental right, participation right, right to information, the right to recreation, and protection right.

Developmental Right: Children have the right to an adequate standard of living, health care, education, service, play and recreation.

Participation Right: Children have the right of freedom to express opinions, to have a say in matters affecting their own lives, to join the association and to assemble peacefully.

Right to Information: Every child has a right to know his basic rights and position in society. Children need information and knowledge for their protection. Also, children need to be provided with safe and protective channels for participation and self-expression.

The Right to Recreation: Every child has a right to spend some time on recreational pursuits like sports, entertainment and hobbies to explore and develop. Some children in Nigeria are not allowed time for recreational activities.

Protection Right: All children have the right to be protected from all types of violence, including physical, emotional, verbal, psychological, sexual, political, gang, domestic, school, township, state, street, community, racial, self-destruction such as drug abuse, smoking, alcohol among others. Childhood should be allowed free, spontaneous expression. (Obiechina 2014: 153-154)

Although Nigeria, like many nations of the world today, has had "permanent comrades", it is sad to note that the issue of child protection came to a dim light from this $21^{\text {st }}$ century. During the colonial era, the Nigerian child's welfare was not mainly a significant concern to the British colonial government. The first legislation of child protection in Nigeria was in 1943 when the Governor-in-council promulgated the Children and Young Persons' Act (CYPA). It is on record that the term 'young person' apparently first appeared with the Children and Young Person's Ordinance (CYPO), 
promulgated in Nigeria in 1943, which defined two categories: a child is under 14. A young person is over 14 and under 17 (Patterson and Annual Reports, the Nigerian Police Force in Fourchard 2006: 122). The Children and Young Persons Ordinance promulgation from Lagos extended to the rest of the geographical entity called Nigeria, and this juvenile justice system was universal.

According to Uduigwomen (2019), between 1943 and 2003, international and regional laws were regulated to avoid children's exploitation. The end of colonialism led to the dominance of the United States of America, championing capitalist ideology worldwide. This move towards capitalism was accompanied by efforts made to regulate children's role to avoid exploitation in this new capitalist order (91). These efforts were seen in 1959, when the United Nations - UN came up with the Declaration on the Rights of the Child and in 1981 when the Organization of African Unity - OAU also came up with its African Charter on Human and Peoples Rights. The Universal Declaration of Human Rights (UDHR) declares that "All human beings are born free and equal in dignity and rights."18 Article 25(2) of UDHR provides that motherhood and childhood are entitled to special care and assistance and, all children, whether born in or out of wedlock, shall enjoy the same social protection. The African Charter on Human and Peoples' Rights provides that States parties should protect the child's rights as stipulated in international declarations and covenants. By this provision, the African Charter effectively endorses internationally accepted principle on Children's rights, including all the provisions on the administration of juvenile justice. Thus, the United Nations and the OAU called for respect for a child's life, emphasising the importance of providing opportunities and facilities for the healthy and dignified development of the child and requested for the child's protection (Uchendu 2007: 117).

To Aderinto (2015: 201), the CYPA OR CYPO was intriguing and innovative, in that the first innovation, which was roundly lauded, concerned the establishment of juvenile courts and a juvenile justice system... and the second innovation... that restricted street trading by children. This innovation implied that child offenders were to be punished, and the government regulated hawking on streets to curtail children hawking. The regulations prohibited all children under 14 from selling petty goods in the street and from "playing, singing, or performing, for profit" (Aderinto 2012: 202).

In 2003, the Nigerian government enacted the Child's Rights Act (CRA), to bring into law the primary role enshrined in the United Nations Convention of the Rights of the Child and the African Union charter on the child's welfare. This act protects the Nigerian child, appropriates penalties for Child Rights abuses and violations, amongst others. However, it is unfortunate to state that the Child Rights Act signed into law by the federal government of Nigeria is yet to be fully functional; also, the implementation and enforcement of the CRA in the state of the federation are slowly functional, and the contents of the CRA has not been made known to the majority of the populace, to know what constitutes an offence and the punishment in the developmental training of the Nigerian child. The judicial arms of government and the police force are yet to be fully conscientized on the CRA, making enforcement and implementation of the CRA difficult (Obiechina 2014: 156). The Child Rights Act 2003 was promulgated into law and was passed by the state assembly and assented to by the state governors 
in twenty-four states: Abia, Akwa-Ibom, Anambra, Benue, Cross River, Delta, Ebonyi, Edo, Ekiti, Imo, Jigawa, Kwara, Lagos, Nassarawa, Ogun, Ondo, Osun, Oyo, Plateau, Rivers, Niger, Bayelsa, Kogi and Taraba (UNICEF 2011: 2).

The general framework within which human rights are protected in Nigeria is enshrined in the 1999 Constitution of Nigeria. The Constitution requires the government to provide free compulsory and universal primary education, free secondary education, free university education, and free adult literacy programs when practicable (Section 18 of the 1999 Constitution in Tajudeen 2015: 47). Furthermore, the structure and contents of the Child Rights Act 2003, coupled with the analysis of state obligations to promote and protect children's rights, that in its rights/responsibilities approach, the act is constitutionally and culturally sensitive, progressive, compatible, relevant, problem-solving and above all, in the best interest and welfare of the Nigerian Child (Tajudeen 2015: 51-52). At this point, it must be noted that although the provisions of the Child Right's Act of 2003 are contemporary and unique, which made provision for the protection of the rights of children, its implementation has been defective. Nigerian laws are very catchy, but the operators are very weak. Once this defect is handled, the Nigerian child would enjoy all their fundamental rights provided by the Child Right's Act. The subsequent section of this paper will elaborate on these defects, specifically in Calabar.

\section{SOCIO-CULTURAL VALUES AND CHILD'S RIGHTS IMPLEMENTATION IN CALABAR: AN APPRAISAL}

The culture of a people is what marks them out distinctively from other human societies in the family of humanity... As it is usually understood, culture entails a totality of traits and characters peculiar to a people to the extent that it marks them out from other peoples or societies (Idang 2015: 97-98). These traits include the people's language, norms, taboos, religion, music, dressing, arts, work, dancing, values etc. On the other hand, values may be ideas that propel man's daily actions, standards that members of the community adhere to in their personal and communal interaction towards achieving the goals (Igboin 2001: 98). Values also determine the appraisal or reprimand of human actions within a geographical entity. In another sense, values refer to 'good' or 'desired' (Igboin 2001: 98). As stated earlier, the city dwellers (Calabar) had a high sense of socio-cultural values that aided in the city's progress. However, this has been marred by some socio-cultural values like twin killing.

Furthermore, it should be noted that Calabar also has a history of the presence of street children. Uduigwomen's study of “History and Impact of Child Streetism in Calabar, 1943-2015" documented this history, stating clearly that it arose, apart from other reasons, from the city's new status as a cosmopolitan town, and right from then, has been a pressing issue. Thus, social values can simply be seen as those beliefs and practices that are practised by any particular society (Idang 2015: 103).

The birth of twins or triplets was accepted as an ill omen in many parts of Nigeria until the intervention of missionaries in the $19^{\text {th }}$ century, notably Mary Slessor in Calabar. Multiple births were regarded as procreative features of animals only, and infants 
so born were usually hidden away or abandoned. This belief is still held in some ethnic groups of the country (Okeahialam 1984: 70). Prior to the arrival of missionaries and particularly Mary Mitchell Slessor (1848-1905) in Africa, ignorance, superstition and negative values made multiple births to be seen as a harbinger of evil. Expounding on this practice in this area, it was posited that "one of the twins was said to be genuine, the other, an impostor. They were both infected and cursed by sharing the same cradle bed; their parents were equally guilty of defilement, particularly the mother" (Udoh 2007: 103). The birth of twins was seen as an evil omen. In order to save the community from the anger and wrath of the deities, the twins were killed together with their mothers. Since Mary Slessor stopped this custom, multiple births are now seen as multiple blessings (Idang 2015: 109). Although this practice ceased to exist, it must be re-emphasised that this cultural belief of the people of Calabar was abusive to children, hence, dented the image of this city's history.

Historically, it was observed that during and even before the Atlantic Slave Trade era, of which Calabar was a significant slave depot due to its proximity to the Atlantic, "the incessant raiding for slaves definitely transformed the lives of children, limited their playtime and choices, and placed the fear of disappearance from parents at the centre of their existence" (Aderinto 2015: 2). In her account of South Eastern Nigeria, Calabar was also inclusive; it was posited that children "were pawns, slaves, serfs, servants, subjects, clients and child brides" (Chapdelaine 2016: 52). Child pawning was a temporal agreement, which could take years pending when agreements are met. It is of record that "Calabar and Bonny were rivals for pre-eminence among the slave ports of Africa, and few places in the world can have seen more misery" (Talbot 1969: 325). This no doubt affected the lives of children in Calabar. This was so serious that the "Colonial authorities began to examine and critique ways in which the Igbo, Efik and Ibibio speaking people in South-Eastern Nigeria set up systems to transfer children" (Chapdelaine 2016: 54), usually as pawns. Internal slavery was in existence during this period; therefore, pawning, child stealing, prostitution, child labour and exploitation were prevalent. Child pawning was an antecedent form of child abuse that characterised Calabar's history.

One major cultural value of Africans and also Calabar dwellers was communal child upbringing. Communalism was also an instigative drive of this polygamous lifestyle by most Africans, including Calabar, and saw many children's birth mainly due to economic reasons. Thus, communalism was eventually replaced by capitalism during the late 1800 s and early 1900 s. This resulted in many social problems to grapple with. The population increase was due to rural-urban rift without corresponding social amenities and welfare, especially in colonial administrative areas like Calabar. Instead of the cherished communalism, which defined the life of the African, a burgeoning societal construct was introduced, alienating and destroying the organic fabric of the spirit of we-feeling (Igboin 2008: 101). Most African scholars have attributed this to the disintegration of families, child abuses and most importantly, the rise of homeless children in urban cities. The traditional African system of child upbringing was termed as child socialisation by Uchendu (2007) where she argued that "Parents, older siblings, and members of the extended family jointly participated in the nurturing and socialisation 
of a child... this ideology of child socialisation as a communal responsibility pervaded nearly all the Nigerian cultural groups during the colonial period" (Uchendu 2007: 118-119).

The sporadic rural-urban drift that accompanied colonialism instigated a change. Okeke (2005: 398), arguing on the changes in traditional institutions and systems due to colonialism and urbanisation, posited that before this change, members of the society were made to "imbibe the ideology of mutual obligations and contribution toward the maintenance of the collective. Because the entire clan is (sic) concerned with maintaining the good name or image of the family, children's activities are closely monitored, and any misbehaviour is swiftly dealt with". Thus, areas with colonial presence were bound to possess dysfunctional families and breed abused children due to a monogenic system's institutionalisation. The impression that child abuse could not occur in traditional African societies as fostered by some sociologist which in their view portray that the extended family as a system provided profound love, protection, security and care to the child within the cultural milieu; hence, no cause for child abuses, stands debatable. Okeahialam (1984: 70) believes that the social advantages of this system tend to minimise the effects of some traditional practices that are abusive to children. Besides, little attention is focused on child abuse due to the prevalence of malnutrition and infections, major paediatric problems. From the preceding, it can be understood that although such views are present, child abuse cannot be changed, and instances highlighted in this study tends to disapprove of this view, as some cultural beliefs in Africa encouraged child rights violations. Thus, various forms of child abuse were inherent in paediatric practice. Many of these are related to the culture and tradition of society. Some are the effects of urbanisation and rural-urban migration, which have resulted from socio-economic and political changes in the country (Okeahialam1984: 70).

On economic value, child birthright from pre-colonial times and even present in some families were/are purely economically driven. The economic values of traditional African society are marked by cooperation. The traditional economy, mainly based on farming and fishing, was co-operative, and children were seen to provide the primary labour force. That is why a man took pride in having many of them, especially males (Idang 2015: 105-106). Children were also social security and economic assets, and parents took pride in having many of them (Idang 2015: 108). Because of this, polygamy was encouraged. Polygamy was considered right because of the civil conditions concerning childbearing in the traditional society (Talbot 1969: 136), and childlessness was seen as a curse and the failure to give birth to male children was blamed on the woman since it was believed that she determines the sex of the child (Idang 2015: 109). Although this practice (Polygamy) is not as prevalent as before in Calabar, child labour persists. With the increase in children hawking goods and providing services in Calabar, child labour has become a deterring factor in implementing the Child Rights Act of 2003. The presence of urban poor and low-income earners in most urban cities has encouraged child rights violations. It is on record that in the mid-80s, hundreds of abused children were living in abandoned public buildings, motor parks, markets and gutters in Calabar, residents, government officials and the police told premium times" 
(Isine 2017: 1).

In the 1990s, this phenomenon still persisted in Calabar, with a report of Premium Times serving as evidence. In 1998, hundreds of abandoned children were roaming the streets of Calabar. While many children hawked food items for their parents and guardians, she said many others scavenged refuse heaps for recyclable plastics, metals and aluminium (Isine 2017:1). This report suggests the reoccurrence of child abuse in Calabar from pre-colonial to colonial and then post-colonial or independence. Could redemption be near? It is uncomfortable and disagreeable to be small (Korczak 2017: 7), therefore in Calabar. Children are small, insubstantial; there is less of them... what is worse, children are weak (Korczak 2017: 8), the reason they are easily exploited. Because children are poor and trapped in material dependency, adults' relationship to children is unjust (Korczak 2017: 12). Children believe life is simple and easy (Korczak 2017: 13). Sadly, what Korczak (2017) has highlighted reoccurs and assumes different forms in the contemporary. Poverty has made more children live and work in the streets, which has increased their vulnerability to the detriment of an appropriate lifestyle. A child who has been physically or sexually abused grows up with deep shame about self and family (Obiechina 2014: 151).

Child labour remains a serious concern in Nigeria, that despite legislations, children of school age are seen daily trading goods on the streets, herding animals, tanning serving as domestic help, selling wares at kiosks, harvesting crops in family farms or commercial plantations, amongst other activities during school hours. In a report issued in 2002, the International Labour Organization maintains that the most significant number of working children between the ages of 5 and 14 live in Asia and Africa. A total of 107 million or $60 \%$ of the world comes from the Asia Pacific region; 48 million or 23\% comes from Sub-Sahara Africa; a total of 17 million or $8 \%$ live in the Caribbean's; 13 million or 6\% are found in the Middle East and North Africa, and 2 million or $1 \%$ is found in the advanced industrialised countries (Ndem \& Michael 2012: 150). In Nigeria, children face the menace of abuse ranging from physical injuries, abandonment, sexual abuse to child labour. In fact, child abuse is becoming alarming in the country. The government's efforts to combat the problem have yielded little or no result (Akpan \& Oluwabamide 2010: 189). To back up this point, it was revealed that Calabar Municipality is not left out because we notice a daily rise in the number of children who litter the streets searching for a living since the Council Area was created in 1991. Its attendant consequences have increased social vices such as drug addictions, robbery, rape, thuggery, prostitution, and alcoholism (Ndem \& Michael 2012: 151).

Street hawking is a negation of the international convention on the rights of the child. It is indeed inhuman for anyone to engage a child in a money-making venture. Such a child is denied primary education, which is another right of every child. Apart from those consequences of child labour we have discussed, there is still the problem of wear and tear (Akpan \& Oluwabamide 2010: 192). Street hawking is relatively common, and child hawkers can be seen in busy areas like the University of Calabar, Marian, Watt, Mount Zion, etc. It is more worrisome in any public gatherings like burial, marriages, school events, carnival (Carnival Calabar, which is a yearly event); child 
hawkers are visibly active, and the government and individuals see no wrong in it. Thus, millions of Nigerian children face particular problems of disadvantage, discrimination, abuse and exploitation, sometimes in appalling circumstances. These problems not only compound the risks of survival and create formidable obstacles for the development of children but are significant challenges in their own right, requiring special protective measures if they are to be addressed effectively (Tajudeen 2015: 47). The changing life pattern, particularly in the cities with inadequate accommodation, lack of recreational facilities, irregular water and electricity supplies, creates a new psychosocial problem, urban stress, which erodes marital harmony. This is worse if the parents are unemployed or have financial difficulties. The child in a large family living in overcrowded one-room accommodation in the peri-urban slum is likely to be abused by an irritable and stressed parent. Lack of provision of adequate educational and recreational facilities in society contributes to the child's emotional and social neglect (Okeahialam 1984: 71-72). A study on child labour and its consequences on the Nigerian economy using 500 respondents revealed that 52 per cent of children are abused in Calabar city (Azi \& Saluhu 2016:26). Therefore, this figure is worrisome and alarming and dents the hospitable image Calabar has been exporting to the world.

Religion (the belief in God) and other religious beliefs is one of Calabar's salient values. It is inarguably that pre-colonial Africa was religiously inclined. Almost every aspect of the African way of life was supernaturally interpreted. The belief that the ancestors played prominent roles in maintaining morality in the community hardly dies, even today (Igboin 2011: 96). However, it is relatively accurate that colonialism altered the Africans' belief and values significantly, just as its structure was almost completely eroded (Igboin 2011: 96). Most religious beliefs and values that trampled or still trample on children's rights existed and still exist. Topmost on the ladder is the belief in witchcraft, which has characterised this area.

The belief in witches' existence and powers has a long and diverse history and are found across a vast range of cultures and traditions. Such beliefs have commonly although by no means always - resulted in persecution, social rejection, discrimination and violence towards those who are believed to be or who identify themselves as witches (Secker 2012: 22). Seeker's research highlighted that accusations of witchcraft usually target already vulnerable groups, such as women, children and the elderly, and have been documented in a large number of countries around the world, including Papua New Guinea, Nigeria, India, Ghana, Uganda, and Tanzania (Secker 2012: 22-23). This practise is common in Africa and has yet received a corresponding reaction to quell this avenue of child abuses from the last assertion. Secker further elaborated that "over the past decade, children have been increasingly falling victim to allegations of witchcraft and suffering significant violations of their rights as a result" (Schnoebelen in Secker 2012: 23). Religious beliefs play a major role in increasing witchcraft accusations against children. Children are primarily accused of witchcraft by either their immediate families or clergy. The key rights affected are the right to be free from violence, abuse and neglect, the right to life, the right to be free from torture, the right to non-discrimination, the right to respect for the views of the child, the rights to food and shelter, and the right to education, although other 
rights, including the right to health, the rights to play and to cultural life, the right to family life and the right to protection against trafficking are also affected (Battarbee, Foxcroft \& Secker in Secker 2012: 26). The possibility of not having children in, on or of the streets in most urban areas of Nigeria seemingly is impossible because as years, decades and centuries pass by, new and emerging conditionings aside unchecked birth rates/procreation and unaffordable housing/urban slums may emerge (like in the case of witchcraft labelling by some churches) (Uduigwomen 2019: 124). From the analysis above, this form of child abuse is worrisome and rather prevalent, and an end seems to be a noble dream. This no doubt has hampered the implementation of the Child's Rights Act. It is important to note that Calabar city dwellers know of personalities and churches that label children as witches. Moreover, this has resulted in an increasing number of street children in Calabar.

Human trafficking, which is the recent common form of child abuse globally, is not left out as one of the ills faced in this city. Recall earlier that child pawning had existed in Calabar during pre-colonial times. This act also necessitated child abuse and human trafficking. As Uduigwomen (2019) highlighted cases of children on the streets in other areas of Nigeria who were trafficked to places like Lagos and Onitsha, human trafficking is the use of deceit and coercion to recruit and transfer persons either internally within the domestic borders of a country or externally across international borders for exploitation. Trafficking in women and children is the illegal trade of human beings for transfer, commercial sexual exploitation forced labour, and it is known as a modern-day form of slavery. Trafficking violates all known standards of human rights and dignity of human. It violates the right to health, right to liberty, equality, and security (Ukwayi et al. 2019: 1). Traffickers target the less privileged and vulnerable people with promises of higher incomes to improve economic situations, support parents and families in villages women and children are the key target group because of their marginalisation in many societies. The United Nations Children Emergency Fund (1998) reported that more than 4000 children were trafficked from Cross River and Akwa Ibom States to other parts of the nation and been trafficked across the border to other nations. States such as Cross River and Edo rank among the main providers of external trafficking in persons to Italy, Spain, Gabon, Benin Republic and Cameroon (Ukwayi et al. 2019: 3). The above illustrates the gravity of child trafficking, and this goes to show that although politicians and lawmakers make tentative efforts, they fail time and time again. When it comes to children, they advise and reflect, but who would naively ask a child for their opinion or approval? What could they have to say? (Korczak 2017: 9) These children have a future, but they also have a past: unforgettable events, memories, many hours if essential solitary reflection (Korczak 2017: 30). If we continue to accept child abuse instead of abhorring it, then the future of protecting the child in Calabar and indeed Cross River state is uncertain. The fact that issues concerning children are handled with no seriousness in Nigeria confirms earlier claims that Nigeria legislates unique laws but do not practice them the way they are grafted.

\section{CONCLUSION}


To conclude, there is a general saying that "children are the future" of any nation. Nevertheless, how do we handle our "future" at present? From this paper, it was highlighted that children have not generally fared well in Nigeria. Although most children are privileged to be brought up properly, the fact remains that Nigeria, as a developing nation associated with a high poverty index, makes incidences of child abuses seemingly inevitable. This study has brought to the limelight that in Calabar, socio-cultural values and belief systems have aided child rights violations right from the pre-colonial era. Although Calabar eventually became a beautiful cosmopolitan area, child rights violation continually dents her image. To this extent, government and society have to ensure that children are given every care, help, protection, training, and education they may need to grow into valuable citizens and members of society. For child welfare to be effective, a combined effort of dedicated social workers, innovative social security system, implementable policymaking, strong advocacy for children, and family and community partnerships is required. A child's right tied with the government's responsibility, family, school, and others will advance Nigeria's status on the international scene. Child's rights should be part of the curriculum from the primary section to know their rights while tender. Children possess seriousness, sagacity and stability, unwavering commitment, expertise in their area, a wealth of fair judgements and assessments, tactful restraint in their demands, sensitive intuition, and an unfailing sense of right and wrong (Korczak 2017: 46). Children demand uniformity of virtues and moments - a universal respect for children's rights.

Let us strike a balance, let us estimate how much of the general budget belongs to children, what share falls to them, but not as a favour, not as charity. Let us thoroughly examine how much we set aside for the use of children's race, the nation of the immature, the class of the serfs. How much is their inheritance, how should it be divided, have we dishonest caregivers not deprived them of it, expropriated it? (Korczak 2017: 28) Therefore, things must be done right in Calabar to live up to its acronym of $\mathrm{C}$ Come A - And L - Live A - And B - Be A - At R - Rest. Children need rest while growing up in Calabar. Their rights should be implemented and abusers prosecuted.

FUNDING: This research received no external funding.

CONFLICT OF INTEREST: The authors declare no conflict of interest.

\section{REFERENCES}

Aderinto, Saheed. 2015. Children and Childhood in Colonial Nigerian Histories. New York: Palgrave Macmillan.

Akoda, Winifred Eyoanwan. 2002. “Calabar: A Cross River Metropolis, 1600-1960.” Unpublished Ph.D. dissertation. Department of History and International Studies, University of Calabar.

Akpan, Nseabasi \& Abiodun J. Oluwabamide. 2010. “The Menace of Child Abuse in Ni- 
geria: A Case Study of Street Hawking in Uyo, Akwa Ibom State." Journal of Social Sciences 24(3): 189-192. DOI: 10.1080/09718923.2010.11892855

Awoniyi, Sunday. 2015. “African Cultural Values: The Past, Present and Future.” Journal of Sustainable Development in Africa 17(1): 1-13.

Aye, UkpongEffiong. 2000. The Efik People. Calabar: Glad Tidings Press Limited.

Azi, Sambo Augustine \& Isah Saluhu Abubakar. 2016. "The Effect of Child Abuse on the Academic Performance of School Children: Implication on the Nigerian Economy." Asia Pacific Journal of Education, Arts and Sciences 3(3): 23-7.

CADIST 3/3/372. 1933. The Divisional Officer to the Senior Resident, Calabar. "A Report of the Qua Clan by Mr. M.O. Alderton, A. D. O. Comments Of.” 13 June1933. Chapdelaine, Robin Phylisia. 2016. "Girl Pawns, Brides and Slaves: Child Trafficking in South Eastern Nigeria, 1920's.” Pp. 51-66 in Children on the Move in Africa: Past and Present Experiences of Migration, edited by Elodie Razy \& Rodet Razy. New York: James Currey.

Ekpe, Bassey. 2016. "Cultural Identity and Diversity among the Efịk and Qua of Calabar.” AKSU Journal of History and Global Studies 2(3\&4): 111-121.

Fourchard, Laurent. 2006. "Lagos and the Intervention of Juvenile Delinquency in Nigeria: 1920-1960.” Journal of African History 115-137.

Hart, Athanasius Kalada. 1964. Report of the Enquiry into the Dispute over the Obongship of Calabar, Official Document No. 17 of 1964. Enugu: Government Printers.

Idang, Gabriel.2015. "African Culture and Values." UNISA Phronimon 16(2): 97-111. Igboin, Benson Ohihon. 2011. "Colonialism and African Cultural Values." African Journal of History and Culture 3(6): 96-103.

Imbua, David Lishilinimle. 2012. Intercourse and Crosscurrents in the Atlantic World: Calabar-British Experience, $17^{\text {th }}-20^{\text {th }}$ Centuries. Durham: Carolina Academic Press. Imbua, David Lishilinimle \& Ekwutosi Essien Offiong. 2011. "Cosmopolitanism, Urbanism and Ethnicity in Calabar Metropolis: The Challenges of Heritage.” Pp. 131-150 in Urbanization and Infrastructure in Nigeria since the $20^{\text {th }}$ century, edited by Abdullahi M. Ashafa. Kaduna: Kaduna State University.

Isine, Ibanga. 2016. "Investigation: Skolombo Boys: How Parents Abused, Abandoned Children on the Streets of Calabar." Premium Times. May 27. Retrieved February 20, 2017 (http://www.premiumtimes.com).

Itakpo, Edim Edim. 1988. The Quas of Calabar. Calabar: Amuko, Graphic and Press.

Korczak, Janusz. 2017. A Child's Right to Respect. Strasboug: Council of Europe.

Latham, A. J. H. 1973. Old Calabar: 1600-1891: The Impact of the International Economy upon a Traditional Society. Oxford: Clarendon Press.

Majuk, Simon. 2001. Understanding History: A Guide for Beginners. Calabar: Fomaprints Ltd.

Ndem, Bassey Enya \& Michael Baghebo. 2012. "Child Labour in Nigeria and its Economic Implications - A case study Of Calabar Municipality.” Research on Humanities and Social Sciences 2(9): 149-159.

Noah, Monday Efiong. 1980. Old Calabar: The City States and the Europeans, 1800-1885. Uyo: Scholar Press.

Obiechina, Georgy Ogonna. 2014. “Violation of Child’s Rights in Nigeria: Implications 
for Child Health." Academic Research International 5(1): 151-159.

Odey, Patrick Oko. 2016. "Urbanisation and Social Vices: The Skolombo Phenomenon in Calabar, Cross River State.” Pp. 388-404 in Urbanization, Security and Development Issues in Nigeria 1914-2014, Festschift in Honour of Professor Enoch Oyedele, edited by P. I. Ukase, E. O. Akubor and A. I. Onoja. Zaria: Ahmadu Bello Press Limited.

Okeahialam, Theodore. 1984. "Child Abuse in Nigeria." Child Abuse and Neglect 3: 6973.

Okeke, Veronica Ifeyinwa. 2005. "African Family in Transition: The Issue of Juvenile Delinquency among Families of Working Mothers." Pp. 397-405 in The Social Sciences and Socio-Economic Transformation in Africa, edited by J. C. Okabunor \& E. E. Anugwom. Nsuka: Great AP Express Publishers Ltd.

Okokon, Joseph \& Arit Charles. 2004. "Family and child labour: a study of child hawkers in Calabar." Journal of Social Development in Africa 19(2): 113-133.

Secker, Emilie. 2012. "Witchcraft Stigmatisation in Nigeria: Challenges and Successes in the Implementation of Child Rights." International Social Work 56(1): 22-36.

Tajudeen, OpeyemiIsola. 2015 "Legal Framework for the Protection Of Child Rights In Nigeria.” AGORA International Journal of Juridical Sciences 3: 46-52.

Talbot, Percy Amaury. 1969. In the Shadow of the Bush. West Port Connecticut: Negro University Press.

Talbot, Percy Amaury. 1969. The Southern People of Nigeria: A Sketch of their History, Ethnology and Languages. Vol. I-1V. London: Frank Cass.

Uchendu, Egodi. 2007. "Recollection of Childhood Experiences During the Nigerian Civil War." Periodical: Africa: Journal of the International African Institute 77(3): 393-418.

Udoh, Emmanuel. 2007. "Mary Slessor in our time: HIV/AIDS.” Sophia: An African Journal of Philosophy 7(2): 99-105.

Uduigwomen, Godspower Andrew. 2019. "History and Impact of Child Streetism in Calabar, 1943 - 2015.” Unpublished M.A Thesis. Department of History and International Studies, University of Calabar.

Ukwayi, Joseph Kinuabeye, Angioha Pius Unim, and Aniah Akomaye. 2019. “Associate Factor of Trafficking in Womenand Children in Calabar, Cross River State, Nigeria." European Journal of Political Science Studies 3(1): 1-15.

UNICEF NIGERIA. 2011. - FACTS SHEET.“Child Rights Legislation in Nigeria.” April 2011.

Uya, Okon Edet. 2009. African History: Some Problems in Methodology and Perspectives. Calabar: CATS Publishers. 


\section{BIOGRAPHICAL NOTE}

Ekwutosi Essien Offiong (Ph.D) is an Associate Professor in the Department of History and International Studies, University of Calabar, Calabar, Nigeria. An active academic and research consultant; her research interest includes, African History, History of Christianity in Africa, Social History and Gender Studies. She was a Fellow and participant at the 12th International UNESCO Fellowship Programme at Maria Grzegorzewska University, Warsaw, Poland in September, 2019

Godspower A. Uduigwomen is an Assistant Lecturer at the University of Calabar, Calabar, Nigeria. He specializes on Childhood Studies, Peace and Conflict Studies, International Studies and Nigerian and African History.

OPEN ACCESS: This article is distributed under the terms of the Creative Commons Attribution Non-commercial License (CC BY-NC 4.0) which permits any non-commercial use, and reproduction in any medium, provided the original author(s) and source are credited.

ARTICLE HISTORY: Received 2020-11-12 / Accepted 2020-04-27 
